\title{
The Implementation of Customs Advance Ruling (AR) Facility as a Trade Facilitation Measure in Bangladesh: Prospect in Retrospect
}

\author{
Mohammad Akbar Hossain ${ }^{1}$ \\ ${ }^{1}$ Customs House, Chittagong, Bangladesh \\ ${ }^{1}$ Department of Accounting and Information System, University of Dhaka, Bangladesh \\ ${ }^{1}$ Institute of Business and Economic Research (IBER) of United International University, \\ Bangladesh
}

Email: akbar762003@yahoo.com

\author{
ARTICLE INFORMATION \\ Received date \\ [08-11-2019] \\ Revision \\ [03-12-2019] \\ Accepted date \\ [04-12-2019]
}

\begin{abstract}
The WTO Trade Facilitation Agreement (TFA) and the WCO Revised Kyoto Convention (RKC) have clearly prescribed their Members to implement Advance Ruling (AR) facilities for avoiding disputes between the Customs authorities and trade communities. If the future disputes can be treated before the arrival of imported or exportable goods at the borders, cross-border trade will be facilitated reducing the cost and time of both the traders and customs. The developed countries have been using the AR facilities for a long time to avoid future disputes, while the developing countries are yet to initiate the journey in full swing. Because of the absence of AR, the customs authorities of the developing countries are bogged down in dealing with the court cases originated from the disputes at the borders. Again, the traders are facing unwanted hassles at borders that increases time and cost of doing business. Bangladesh implemented Customs AR on tariff classification in 2016. This article endeavors to examine the AR regime of Bangladesh. In particular, it analyzed the context that prompted Bangladesh customs not to implementing AR in its full scope i.e. for valuation, origin, duty drawback, etc. The limited interests of businesses towards Customs AR are also explored in this study. The study finds that the traders are highly benefited from AR. However, as the AR facilities are given only for classification, and there are some other platforms for having remedy for classification, the facilities could not attract the traders as it was expected.
\end{abstract}

Key Words: Advance Ruling (AR), Bangladesh Customs, Classification Rulings, TFA, Trade Facilitation 


\section{INTRODUCTION}

\subsection{Background}

The WTO Trade Facilitation Agreement (TFA) and WCO Revised Kyoto Convention (RKC) have clearly prescribed their Member countries to implement Advance Ruling (AR) facilities for avoiding disputes between the Customs authorities and trade communities. If the future disputes can be treated before the arrival of imported or exportable goods at the borders, cross-border trade will be facilitated reducing the cost and time at clearance stage. At the same time, AR contributes to lessen the discretions of officers resulting in misuse of authority, and at times corruption in Customs administrations by ensuring predictability of valuation, tariff classification, and origin before the submission of import documents. Though RKC had coined the matter with the inception of RKC, the WTO obligated the issue further whilst concluding the historic TFA at Bali, Indonesia. Bangladesh as a signatory of TFA and RKC, has implemented the AR facility partially (only for classification) in 2016. This paper examines the context of implementation of AR in Bangladesh including the reasons for partial implementation of AR and causes behind business community's limited enthusiasm for obtaining customs AR.

\subsection{Definition of Advance Ruling}

According to $\mathrm{WCO}$, an advance ruling on classification, origin or valuation is an official written decision issued by a competent authority which provides the applicant with an assessment of: (i) the classification of goods in the Customs tariff nomenclature of the respective country or Customs territory; (ii) origin; or (iii) the treatment which should be applied on a certain element for the determination of the Customs value, prior to an import or export transaction, for a specified period ${ }^{1}$. The Australian Customs and Border Protection Services defined that ARs are the formal advices on how Customs and border protection will apply certain laws to goods for importation. Customs AR is a proven trade facilitation tool for both traders and Customs administrations that enhance the certainty and predictability in Customs operations ${ }^{2}$. The UNCTAD view customs advance ruling for Customs purposes as a binding official decision prior to an importation or exportation, issued by a competent Customs authority in writing, which provides the applicant with a time-bound ruling on the goods to be imported ${ }^{3}$.

\footnotetext{
${ }^{1}$ Technical guidelines on advance rulings for classification, origin and valuation, WCO, June 2018.

${ }^{2}$ Advance Rulings: Tariff, Valuation and Origin Advice, Australian Customs and Border Protection Service.

${ }^{3}$ UNCTAD Trust Fund for Trade Facilitation Negotiations Technical Note No. 22, Jan 2011.
} 


\section{Literature Review}

Advance Ruling facility has become a major tool for the stakeholders to avoid hassle at import stage. AR has been popular not only in Customs administrations, but also in tax administrations. Some studies have been carried out specifically on ARs. While discussing about implementation methods of AR, the USAID (2011) paper stated that advance rulings are a proven means of facilitating trade, promoting transparency and consistency in customs operations, and fostering the participation of small and medium-sized enterprises in global commerce. Well-implemented advance ruling systems provide certainty to traders and their agents about how their goods will be treated at the time of import, promote consistent application of customs rulings and law, foster trust between customs and trade, and provide a transparent framework that encourages compliance. According to Deloitte (2019) an advance ruling mechanism goes a long way in providing certainty to taxpayers. Prebble (1996) described that it seems likely that a comprehensive and effective rulings procedure promotes respect for and compliance with fiscal laws. Certainly, an effective rulings procedure will generally promote good relations between the revenue authorities and the taxpayer. Chen (2016) stated that the advance ruling system for tariff classification is expected to grant more legal certainty to international traders because AR provides legally binding tariff classification decision in advance. Such a system is important in the facilitation of international trade. Weerth (2018) pointed out that article 3 of the WTO TFA requires each TFA member to issue advance rulings in a reasonable time that are binding on the applicant and the customs authorities of the issuing country. Such binding advance rulings cover tariff classification that is crucial for the calculation of import duties and tariffs.

\section{Problem Statement}

Trade facilitation has been one of the top priorities for every country to boost its economy. To do so, uninterrupted cross-border trade is very important. The countries have taken various initiatives to facilitate trade. AR is regarded as one of the strong tools for trade facilitation (TF). The developed countries have initiated ARs on many issues though the WCO has clearly emphasized on three areas: classification, valuation, and origin. Many developing countries are yet to introduce the $\mathrm{AR}$ facilities even on the aforesaid three areas. Bangladesh has institutionalized AR only on classification. 
Although Bangladesh has already implemented customs AR for tariff classification, she did not implement AR on valuation, origin, or duty drawback yet. Further, after stocktaking of AR decisions, it is found that since the introduction of AR in 2016, only 20 ARs on classification has been issued. This speaks about the limited interest of business community in getting customs AR. The reasons for limited version of AR implemented by Bangladesh Customs is not known or explained. After comprehensive literature review, the author did not come across any evidencebased study as to why the authorities refrained from the implementation of AR in its full coverage. The reasons for limited response by business to obtain customs AR are also not explored in any study. The trade community is denied the full benefits of this TF measure due to the AR provisions being confined to tariff classification only (in this study, it has been termed "the limited version" of AR). This study is an attempt to fill the void. The study endeavors why Bangladesh Customs did not implement AR on important issues such as customs valuation, origin, duty drawback, etc. so far; what factors influence the business communities not to be interested in AR facilities? Finally, the study attempted to find out the weaknesses of the existing AR system.

\section{Methods of data collection}

A qualitative research design has been followed in conducting this exploratory study. In order to examine the existing scenarios of AR facility from practical perspectives, some in-depth interviews were conducted during July-Aug, 2019. Since the selected interviewees are the main stakeholders of the AR facilities, their experiences would show the real picture - whether the system is functioning well or it requires further updating. Out of 10 interviewees, 5 key respondents from business community, 3 mid-level officials from Customs, and 2 officials from Clearing and Forwarding $(\mathrm{C} \& \mathrm{~F})$ Agents Association, Chittagong were selected and their informed consents were obtained before going for interview. Each interview conducted lasted between 40-60 minutes. During the interviews, the author mainly asked: (a) whether the existing AR facility is fulfilling the expectations of the stakeholders, (b) does the existing AR mechanism have any impact on trade facilitation? (c) What are the weaknesses of the current system? (d) Should the authorities introduce AR on other customs matters such as valuation, origin, duty drawback, etc.? Moreover, during the author's tenure with the USAID BTFA Project, the author had had the opportunity to talk with exporters, importers, C\&F Agents, and shipping agents on 
this issue. The study is mainly developed on the basis of the practical experiences, interviews and interactions with the key stakeholders.

\section{Significance}

This study will help the policymakers and the business come up with pragmatic measures and preparations to implement $\mathrm{AR}$ in its full scope, and thus benefit the business in terms of reduced time, reduced cost, and increased competitiveness. The findings of this study also provide an indication of areas where necessary revisions/changes may be made to make AR regime more effective and trade facilitating.

\section{Legal Framework}

Both the RKC and TFA have clearly set up legal framework for AR mechanism. As a requirement of these agreements, the signatories have included the matters into the local laws of their countries. Bangladesh as a signatory of both the instruments have included the legal basis into the existing Customs Act and issued a comprehensive Statutory Regulatory Order (SRO) to implement AR facility on tariff classification. The legal texts are given below before moving to the practical discussions:

\subsection{Revised Kyoto Convention (RKC)}

Chapter 9 of the RKC detailed the information, decisions and rulings supplied by the customs. The RKC Standard 9.9 clearly describes the matter as follows:

"The Customs shall issue binding rulings at the request of the interested person, provided that the Customs have all the information they deem necessary."

\subsection{WTO TFA}

Article 3 of the WTO TFA highlighted the issue of Advance Ruling. The text is given below:

\section{“ARTICLE 3: ADVANCE RULINGS}

1. Each Member shall issue an advance ruling in a reasonable, time bound manner to an applicant that has submitted a written request containing all necessary information. If a Member declines to issue an advance ruling it shall promptly notify the applicant in writing, setting out the relevant facts and the basis for its decision.

2. A Member may decline to issue an advance ruling to an applicant where the question raised in the application: 
a. is already pending in the applicant's case before any governmental agency, appellate tribunal or court; or

b. has already been decided by any appellate tribunal or court.

3. The advance ruling shall be valid for a reasonable period of time after its issuance unless the law, facts or circumstances supporting the original advance ruling have changed.

4. Where the Member revokes, modifies or invalidates the advance ruling, it shall provide written notice to the applicant setting out the relevant facts and the basis for its decision. Where a Member revokes, modifies or invalidates advance rulings with retroactive effect, it may only do so where the ruling was based on incomplete, incorrect, false or misleading information.

5. An advance ruling issued by a Member shall be binding on that Member in respect of the applicant that sought it. The Member may provide that the advance ruling be binding on the applicant.

6. Each Member shall publish, at a minimum:

a. the requirements for the application for an advance ruling, including the information to be provided and the format;

b. the time period by which it will issue an advance ruling; and

c. the length of time for which the advance ruling is valid.

7. Each Member shall provide, upon written request of an applicant, a review of the advance ruling or the decision to revoke, modify or invalidate the advance ruling.

8. Each Member shall endeavor to make publicly available any information on advance rulings which it considers to be of significant interest to other interested parties, taking into account the need to protect commercially confidential information.

9. Definitions and scope:

1. An advance ruling is a written decision provided by a Member to an applicant prior to the importation of a good covered by the application that sets forth the treatment that the Member shall provide to the good at the time of importation with regard to:

i. $\quad$ the good's tariff classification, and

ii. $\quad$ the origin of the good; 
2. In addition to the advance rulings defined in subparagraph 3.9 a., Members are encouraged to provide advance rulings on:

$i$. the appropriate method or criteria, and the application thereof, to be used for determining the customs value under a particular set of facts;

ii. the applicability of the Member's requirements for relief or exemption from customs duties;

iii. $\quad$ the application of the Member's requirements for quotas, including tariff quotas; and

iv. any additional matters for which a Member considers it appropriate to issue an advance ruling.

3. An applicant is an exporter, importer or any person with a justifiable cause or a representative thereof.

4. A Member may require that an applicant have legal representation or registration in its territory. To the extent possible, such requirements shall not restrict the categories of persons eligible to apply for advance rulings, with particular consideration for the specific needs of small and medium sized enterprises. These requirements shall be clear and transparent and not constitute a means of arbitrary or unjustifiable discrimination."

\subsection{The Customs Act, 1969}

Section 219A of the Customs Act, 1969 has empowered the Government of Bangladesh to make rulings on customs matters. The said Section detailed the matter as follows:

"Power to make customs rulings.- (1) On an application by any person or on a reference by an officer of customs not below the rank of Commissioner or of its own motion, the Board may make customs rulings in respect of any matter specified in the application or reference, as the case may be, if the point raised in the application or reference relates to application of any provision of this Act or the rules to a specific situation or if such point relates to any tariff classification or duty rates or valuation of any goods for customs assessment purpose.

(2) A customs ruling may be made within thirty working days of the receipt of the application or the reference, as the case may be. 
(3) The Board may decline to make a customs ruling on the ground of insufficient information furnished or in the absence of conclusive evidence provided in support of the contentions in the application or the reference.

(4) The rulings made by the Board shall be binding upon the concerned persons and officers.

(5) The Board may from time to time review and amend a customs ruling to correct any error contained in that ruling."

Under the above Section of the Customs Act, Bangladesh Customs has issued a comprehensive SRO No. 188-law/2016/37/Customs, date: 2 June, 2016, for the implementation of Advance Ruling on tariff classification. The SRO also entails the form and guidelines to fill up the form easily.

\section{AR Facilities in Bangladesh}

\subsection{Economic Profile of the country}

Bangladesh is a country of South Asia that shares land borders with India to the west, north, and east, with Myanmar to the east, and with the Bay of Bengal to the south. This is the $8^{\text {th }}$ populous country of the world with around 163 million people. The land area of the country is 147,570 square kilometers, one of the tiny countries of the world ( $92^{\text {nd }}$ largest). Therefore, the country has to move with huge population with the tiniest land area. In terms of market exchange rate, Bangladesh has the world $39^{\text {th }}$ largest economy. Again, in terms of purchasing power parity, it has the $29^{\text {th }}$ largest economy which ranks second in South Asia, after India. This is one of the fastest-growing economies, as well as one of the fastest growing middle-income countries with a rate of 7.3 percent real GDP growth. According to the IMF, its per-capita income was US $\$ 1,888$ in 2018 , with a GDP of $\$ 314$ billion.

\subsection{Existing AR Mechanism}

Bangladesh, as a signatory of WCO RKC and WTO TFA, has initially introduced AR on tariff classification. Since Bangladesh is the signatory of both the instruments, these two agreements have clearly mandated Bangladesh to implement AR. However, the Customs Act 1969 empowered the government to introduce AR.

The government has issued a comprehensive SRO that detailed the procedures of AR. The process of $\mathrm{AR}$ is as follows: 


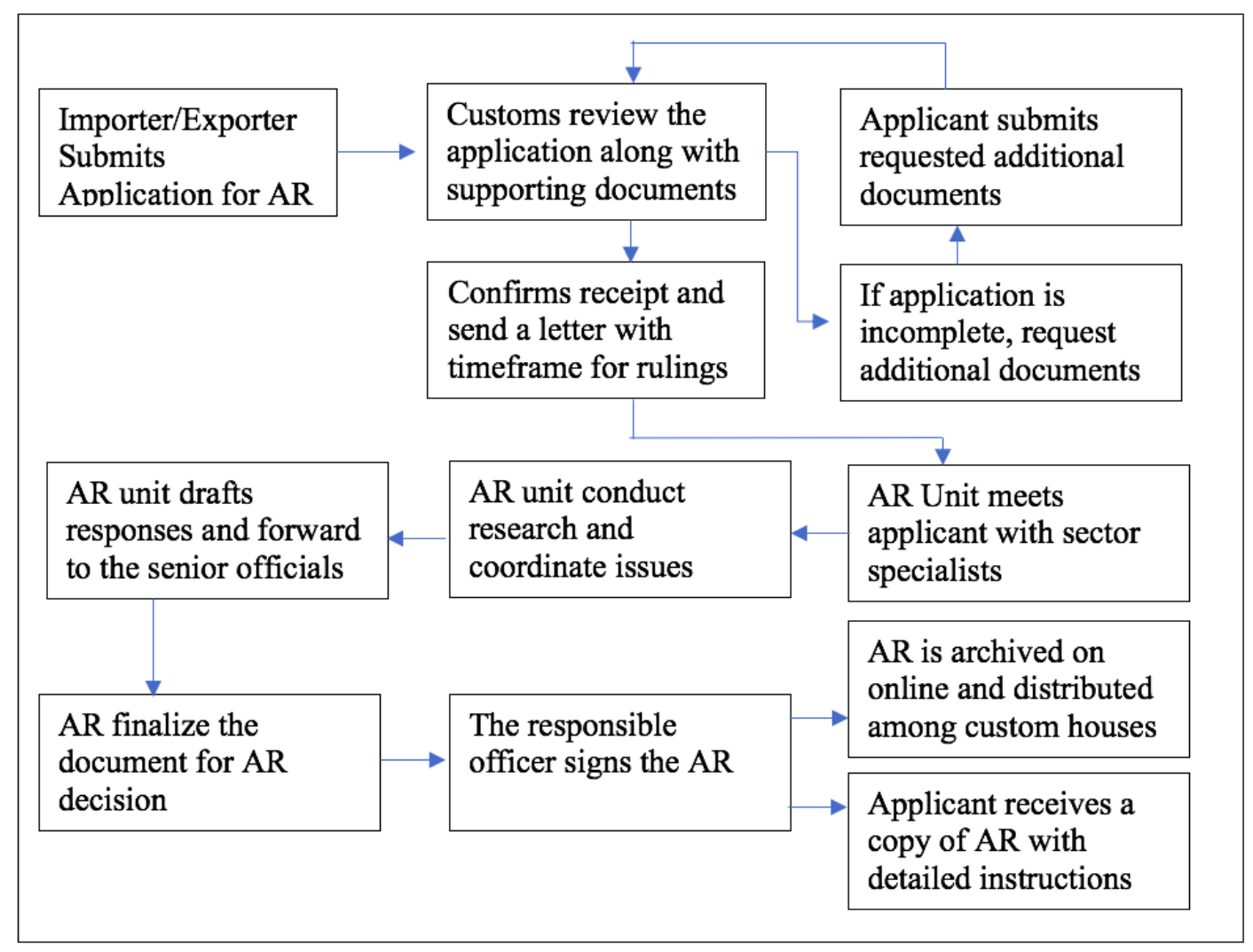

Figure 1. Process of AR

Source: AR Rules, 2016

\subsection{Main Features of AR in Bangladesh}

The SRO 188-Law/2016/37/Customs date: 2 June 2016 detailed Customs AR Rules 2016. The said SRO lucidly explained the guidelines with necessary application form. The main features of the AR procedures are briefly discussed below:

\subsubsection{Organizational Structure of AR Unit}

According to the guidelines of the said AR SRO, an AR Unit has been established in the National Board of Revenue $\left(\mathrm{NBR}^{4}\right)$. The Unit consists of the following officers:

(a) Head of the Unit is Member (Customs Policy)

(b) First Secretary of NBR who is responsible for AR issues

(c) Second Secretary of NBR who is responsible for AR issues will be working as Member Secretary of the Unit;

(d) To conduct the activities of AR, the president of the Unit is empowered to co-opt any specialist on respective area, any customs officer, or any person to work in the Unit if needed.

\footnotetext{
${ }^{4}$ The NBR is the Headquarters of Bangladesh Customs.
} 


\subsubsection{Terms of References (ToR)}

The ToR of AR Unit is as follows:

(a) Determining the classification of any product;

(b) Informing the respective persons about any legal or procedural changes of tariff classification that affects the existing rulings;

(c) Usages and implementation of AR,

(d) Management and monitoring of AR; and

(e) Establishment of AR database and making that database publicly available.

\subsubsection{Process of application}

(a) Any person can apply to NBR for ARs regarding classification before making exportation or importation of any goods;

(b) Any importer, exporter or any representative nominated by them can also apply;

(c) Any person, or his representative, who is involved with the applied matters can apply;

(d) The applicant can submit his application in person, by post, by courier service, e-mail or by fax;

(e) A demand draft or pay order of $2000 \mathrm{Taka}^{5}$ needs to be submitted along with the AR application;

(f) In the case of import and export, the application for AR is required to submit at least 60 days before the submission of Bill of Entry or Bill of Export;

(g) Any person can submit more than one AR applications at a time;

(h) One application is required to submit for each item;

(i) The AR Unit has to circulate the decisions within 45 days since receiving the application.

\subsubsection{The AR will not be issued on the following cases}

(a) If the applied matter is pending unresolved before any governmental agency, Customs, Excise and VAT Appellate Tribunal or Court; that means if anything is sub judice, the AR Unit will not make any decision;

(b) If the matter has already been decided by the Customs, Excise and VAT Appellate Tribunal, or Court;

(c) In the cases, where all material facts cannot be determined perfectly.

\subsubsection{Use of AR}

\footnotetext{
${ }^{5}$ Bangladeshi Currency
} 
(a) The AR of NBR is a compulsion for the customs authorities and applicant, moreover, while dealing with the identical products, any importer, exporter, or person will be able to use the AR given on the identical item;

(b) Any AR will be in effect for 18 months since the date of issuance;

(c) If the applicant is aggrieved with the decision of AR Unit, the applicant is allowed to make a review petition to the AR Unit within 60 days since being aware of the decision.

\subsection{Background that encouraged Bangladesh to implement AR}

Bangladesh has signed and subsequently ratified WTO TFA. As article 3 of the TFA is regarding the implementation of AR, Bangladesh has included the AR in the legal framework of the Customs Act, 1969 in 2014. However, as a developing country, Bangladesh has been supported by the international donor organizations i.e. USAID, ADB, World Bank Group (WBG) to fully implement WTO TFA. The USAID Bangladesh Trade Facilitation Activity Project (BTFA) has assisted the NBR to implement few trade facilitation measures including AR and National Enquiry Point (NEP) in Bangladesh. The BTFA has drafted the comprehensive AR SRO, as well as arranged training and awareness workshops for both the customs officers and traders. Discussions with the stakeholders (business community and customs officials) reveal that it was the resource commitment by the USAID project, and their persuasion with the NBR to achieve tangible outcome (i.e. to show deliverables achieved) as well as NBR's realization about the importance of AR as a trade facilitating tool and positive response thereof combined resulted in the adoption of AR regime in Bangladesh Customs. In the beginning, the NBR has started AR in a limited version i.e. with goods' tariff classification only.

\subsection{Assessment Committee for Tariff Classification}

Since the inception of the system, the AR Unit did not receive quite a good number of applications. They issued around 20 ARs so far. The poor number of ARs show that the users are not aware of the system. However, another important issue that helps the users bypass the AR Unit is the presence of Assessment Committee and Valuation Committee in all Custom Houses.

Assessment Committee is a platform that assists the importers to settle their dispute regarding HS Codes. Assessment Committee is headed by an Additional Commissioner, and consists of Joint Commissioners, Deputy Commissioners, and Assistant Commissioners of respective Custom House. Additionally, the representatives from the C\&F Agent Association and Federation of Bangladesh Chambers of Commerce and Industries (FBCCI) work as the member 
of Assessment Committee. When the importers are not satisfied with the classification decision of the Customs authorities, they apply to the Commissioner of Customs to refer the disputed matters to the Assessment Committee. Then, the head of Assessment Committee will invite the members to attend the meeting arranged to discuss the disputed matters, where customs authorities and the importers both parties can raise their positions. Sometimes, the committee invites the experts from certain sectors for their expert comments and interpretations. Committee also sends the sample of the products to chemical lab for chemical analysis if needed. Afterwards, hearing the experts' comments, and analyzing the matter in detail, the committee makes a decision. In many cases, the importer gets right and reasonable solution in this forum. As the business communities and the importer can raise their voices in this forum as a member of the committee, they respect the decision. So, they further do not need to go anywhere else. The importer may import the product without being quite sure of the HS Code in some cases, and afterwards, if they face any problem, they certainly know that there is a neutral forum, where they will get justice. Therefore, the number of applications for AR is not increasing significantly. About the limited interest in getting customs AR, the Bangladesh reality also demands a consideration. Once an AR is issued by the Customs authorities, it is binding on both trade and customs in all customs stations, and there is no scope to avoid the classification. Should the tariff classification have given in the AR goes against the traders' view i.e. if the HS Code given in the AR attracts a higher rate of duty than the perceived one, there is no scope to change that in their favor. But, in the Customs House/Station, they can try and at times, can convince the assessing officer and get a favorable classification decision. This also makes them happy to try luck and exploit the existing assessment mechanism (which is not much efficient) before going for inflexible AR. The comment of a leader of the C\&F Agents Association (importer representative) lends support to the aforesaid observation:

"In assessment stage, we have a say and we can try our best to get a favorable decision through persuasive measures. In a good number of cases, it works in our favor. In some cases, we can take the benefit of unskilled assessment process or relatively new officers or absence of institutional memory. This is not possible in the case of customs AR. So, we are rather happy with our customs station-based systems of assessment (HS codes, valuation in particular), where we can end up paying less in a considerable number of cases." 
Some respondents clearly pointed out the disputes regarding valuation at the import stages. They said that $\mathrm{AR}$ on valuation could have encouraged the stakeholders to use this facility. The comment of one representative of traders' community may be mentioned here:

"In many cases, we have to face difficulties with customs valuation while assessing our imported goods. As WTO Valuation Agreement has some grey areas, customs officers sometimes use their discretionary power to rule out transaction value. If we could get a platform like AR to settle the dispute before arrival of goods, clearance of imported consignments would have been easier and faster at the Custom Houses/Station without making any debate with the customs officers."

\section{Findings}

As a requirement of WTO TFA, Bangladesh has introduced AR mechanism formally only for tariff classification. Still there are some challenges that have slowed down the expansion of AR regime. So, yet it is not as popular to the stakeholders as expected. To have the insights and answers of the research questions, 10 persons have been interviewed. The interviewees have expressed their views on existing problems and prospects of the AR facility. The following challenges have been prepared on the basis of the interview findings and experiences of the business communities, as well as the customs officers, who work at the ground:

\section{(a) Inadequate Awareness}

The importers and exporters are not well aware of the matter. The business communities could not circulate the issue among the community members. However, sufficient number of interactive sessions for the trade bodies have not been arranged by the NBR to make the AR system popular.

\section{(b) Fear of public office}

The traders are afraid of the government offices because of red-tapism. They basically think that if they disclose the matter earlier in the customs AR application, they may face unwanted problem or other competitors may take benefit of it. They were also found quite uncertain about the "would be decision" on their AR application. 


\section{(c) Automation}

Under the existing AR system, an applicant can submit application online. But the stakeholders are afraid of using automated devices. In some cases, the small and medium size industries even do not have these facilities to process the application online.

\section{(d) Training}

Training for the stakeholders is necessary. The applicants require training to reap the benefits of the system. Moreover, training for the officers is also very important to process the application within shortest possible time.

\section{(e) Inclusion of new areas}

Inclusion of new areas into the AR regime is another challenge. The authorities need to include valuation, origin and duty drawback issues as soon as possible. In most of the cases, it was found that the dispute is regarding the value. But there is no forum for determining value before the importation of goods.

\section{(f) Appeal and Review}

A critical analysis of the AR regulations made it clear that the review mechanism in the current AR SRO lacks objectivity. In addition, in the case of appeal against the decision of AR unit, the traders are allowed to make a review to the same unit. The appellate authority is not separate from the decision-making body.

\section{Conclusions and Recommendations}

The countries across the world strive to secure a respectable rank in the ease of doing business index of the World Bank. The recent ease of doing business index 2020 ranked Bangladesh at 168 out of 190 countries. This scenario reflects the poor regulatory and reform performances for doing business. The government has already taken a plethora of reform initiatives to make a business-friendly environment. However, to attract foreign direct investment (FDI), the developing countries need to facilitate cross-border trade. AR is regarded as one of the strong elements as it reduces the dispute and boost the confidence of business communities.

The paper suggests the following measures that may further enhance the AR regime in developing countries like Bangladesh: 


\section{Expansion of scope of customs AR facilities}

AR regarding customs valuation and origin should be introduced along with the existing tariff classification to be fully aligned with the WTO TFA. This will not only reduce the disputes at border points, but also decrease the time and cost of clearance. Furthermore, the number of court cases on customs valuation will also be reduced.

\section{Reaching out to stakeholders}

Awareness among the stakeholders about the importance and use of AR should be prioritized so that they feel encouraged to utilize this initiative. The authorities should emphasize on arranging seminar and workshop to aware the stakeholders about the AR facilities.

\section{Trainings for traders and officers}

Adequate number of training sessions for the business communities have to be arranged so that they can easily understand the operational and legal issues of AR facility. Training for customs officers, who are working at the ground, should also be arranged regularly so that they can implement the rulings, and encourage the stakeholders to utilize the potentials of AR.

\section{Capacity building of AR Unit}

Adequate theoretical and practical training sessions have to be arranged for the officers involved with the AR Unit. In addition, the authorities can arrange study tour for the officers to visit some developed countries to observe the best practices. The authorities should make a pool of local trainers or experts, who will train the officers on AR.

\section{Automation}

The whole AR facilities should be automated. The authorities should encourage and facilitate the traders to be a part of automated environment for sending the AR application online. Similarly, full automation of AR Unit will ensure that the applicant does not require to visit the unit in person.

\section{Appeal or review process}

Last but not least is that the appeal or review of AR decisions may be entrusted with a neutral body or at least with officials who have not been involved, in any stage, with the AR decision.

The RKC and TFA both the instruments encourage (depending on the Members commitments) the Members to issue AR so as to avoid dispute for facilitating trade. Thus, it is high time for the countries to speed up the process to get the benefits that ultimately increase the economic competitiveness of the countries. Bangladesh has initiated the journey, and surely the 
country will accommodate valuation, origin, drawback and some other important matters within the framework of AR to ease cross-border trade given her strong commitment to regulatory and procedural reforms. To conclude, it can be said that the prospect of a full version AR is bright in Bangladesh; Customs AR would provide certainty and predictability to the business community with regard to tariff classification and valuation which businesses value most.

\section{References}

Bangladesh \& Bangladesh Economy. In Wikipedia. Retrieved November 2, 2019 from https://en.wikipedia.org/wiki/Bangladesh

Chen, Shu-Chien, In the Name of Legal Certainty? Comparison of Advance Ruling for Tariff Classification Systems in the European Union, China and Taiwan (August 29, 2016). World Customs Journal Volume 10 Number 2. Available at SSRN: https://ssrn.com/abstract=2831508 or http://dx.doi.org/10.2139/ssrn.2831508

Deloitte. (2019). Authority for advance rulings in indirect taxes - A critical analysis. Deloitte Touche Tohmatsu India LLP. Member of Deloitte Touche Tohmatsu Limited. Available at: https://www2.deloitte.com/in/en/pages/tax/articles/advance-ruling-indirect-taxes.html

Hossain, A. \& Yusuf, M. (2019). Application of post-clearance audit (PCA) as a trade facilitation tool in Bangladesh: Challenges and needed initiatives. World Customs Journal. Volume 13, Number 1, pp. 153-164. Available at: https://worldcustomsjournal.org/Archives/Volume\%2013\%2C\%20Number\%201\%20(Mar\% 202019)\%20copy\%201/1877\%2002\%20WCJ\%20v13n1\%20Hossain\%20and\%20Yusuf.pdf ? $\mathrm{t}=1563333690$

National Board of Revenue (NBR). (2019). The Customs Act 1969. Dhaka: NBR. Available at: http://www.bangladeshcustoms.gov.bd/legislation/customs_act/123

National Board of Revenue (NBR). (2019). The Advance Ruling Rules, 2016. Dhaka: NBR. Available at: http://www.bangladeshcustoms.gov.bd/legislation/advance_ruling

Prebble QC, John, Advance Rulings: A Proposed Procedure (1996). Striking the balance: tax administration, enforcement and compliance in the 1990s, pp. 94-129, M. Gammie, A. Shipwright, eds., Institute for Fiscal Studies, 1996. Available at SSRN: https://ssrn.com/abstract=1604903 
United Nations Conference on Trade and Development (UNCTAD). (2011). Trust fund for trade facilitation negotiations technical note 5: Advance Rulings. New York and Geneva: United Nations. Available at: https://unctad.org/en/Docs/TN22_AdvanceRulings.pdf

United States Agency for International Development (USAID). (2011). Advance Rulings Resources Guide. Produced by Nathan Associates Inc. Washington D.C: USAID. Available at: http://www.tfafacility.org/sites/default/files/case-studies/usaid_advance_ruling_guide.pdf Weerth, Carsten (2018) : Advance rulings and binding pre-entry tariff classification according to Article 3 TFA: Situation 2018 - still a long way to go, World Customs Journal, Volume. 12, Number 2, 2 31-50. Available at: https://worldcustomsjournal.org/Archives/Volume\%2012\%2C\%20Number\%202\%20(Sep\% 202018)/1855\%2001\%20WCJ\%20v12n2\%20Weerth.pdf

World Customs Organization (WCO). (2018). Technical guidelines on advance rulings for classification, origin and valuation. Brussels: WCO. Available at: http://www.wcoomd.org//media/wco/public/global/pdf/topics/origin/instruments-and-tools/guidelines/guidelines-onadvance-rulings-for-classification-origin-and-valuation.pdf?db=web

World Customs Organization (WCO). (2000). International Convention of the simplification and harmonization of customs procedures. Brussels: WCO. Available at: http://www.wcoomd.org/en/topics/facilitation/instrument-andtools/conventions/pf_revised_kyoto_conv.aspx

World Trade Organization (WTO). (2014). Agreement on Trade Facilitation. Geneva: WTO. Available at: https://www.wto.org/english/tratop_e/tradfa_e/tradfa_e.htm

World Bank Group (WBG). (2019). Doing Business 2020: Comparing Business Regulation in 190 Countries. Washington D.C: WBG. Available at: https://openknowledge.worldbank.org/bitstream/handle/10986/32436/9781464814402.pdf 